\title{
針対平板電極における放電空間の負イオン 風速分布
}

\author{
正員足立 宜 良 (山口大) \\ 正員 增 田閃一（東大） \\ 正員阿久津 顕 右 (東大)
}

\section{1.まえがき}

|近年，電気集じん装置（以下 EP と省略する）の粒 子捕集過程拉よび捕集効率に及ぼす㮔々の現象が再び 問題視されて研究が行なわれている。とのうちでイオ ン風作用力によるダスト粒子捕集效果(1)(2)についてむ 種々検討がされてきている。こてでいうイオン風は電 気風，コロナ風，電風之も呼ばれ，古くから知られて いて，その研究の歴史について Robinson 氏(3) が詳し く報告している。

ここでまずイオン風について簡単に説明する。不 平等電界においてコロナ開始電生以上の電王になると 電界の集中した部分にコロナと呼ばれる電離域からイ オンシャワーが発生する。各々のイオンは，電界強度 とイオン移動度の積で表わされる速度で対極へ移動す る。このイオンが保有する運動エネルギーを衙突など によって中性分子代分から与え，イオンならびに中性 分子上むどむ対極へ向加てて移動する。乙れらの移動 がイオン風である。篻者らの一人は，正イオンまたは 負イオンで発生するイオン風をそれぞれの特性が異な ること加ら正イオン風または負イオン風(4) 上呼えで区 別している。

本研究は，EP 内でのイオン風作用力がダスト粒子 捕集過程比よ゙のような影響を与えるが文献 $(4)$ 参照〕 という問題解決の手がかりを得るために行なった基整

\footnotetext{
Velocity Distribution of Negative lonic Wind in the Corona Discharging Space with Needle to Plate Electrodes. By Tada yoshi Adachi, Member (Faculty of Engineering. University of Yamaguchi), Sen-ichi Masuda, Member \& Kensuke Akutsu, Member (Faculty of Engineering, University of Tokyo).

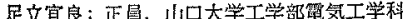

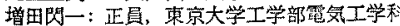

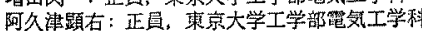

的研㚾である。装置として，EP の基本モデルとして よく使用される針対平板電極を用い，乙の放電空間汇

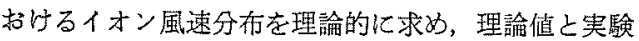
值との比較検討を行なった。なお，理論值は Poisson の式学解くことによって得られた空間電荷分布之電界 強度分布から，イオン倠く空間のクーロン力密度分 布考求め，乙の分布を外力分布上する Navier-Stokes の式を解いて得たすのである。実鈳値はシュリーレン 法 $^{(5)}$ とレーザ・ドプラ流速計による方法(6) との二つの

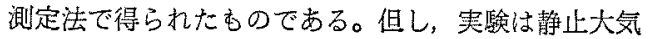
中で行なった。結果として，て机らの実験值と理諭値 との間にかなり良い一致が得られた。

\section{2. ポアソン方程式による電界分布の計算}

第 1 図に示す針対平板電極で構成される空間の電界 分布をコンピュータによって計算して求める。その出 発点となる基本方程式住，次化示すポアソンの式上電 流速続の式である。なお，ての空間を回転対称系とし て取报うので，以㣪，円筒座標系を用いること炕する。

$$
\begin{aligned}
& \frac{\partial^{2} \phi}{\partial r^{2}}+\frac{1}{r} \frac{\partial \phi}{\partial r}+\frac{\partial^{2} \phi}{\partial z^{2}}=-\frac{\rho}{\varepsilon} \\
& \frac{\partial j}{\partial r}+\frac{j}{r}+\frac{\partial j}{\partial z}=0
\end{aligned}
$$

ここで， $\phi$ はポテンシャル $(\mathrm{V}), \rho$ は空間電荷密度 $(\mathrm{C} /$ $\left.\mathrm{m}^{3}\right), \varepsilon$ は誘電率， $j$ は電流密度 $\left(\mathrm{A} / \mathrm{m}^{3}\right)$ である。なお (1) 式の右刃を零とした次に示す(3)式がラプラスの 式で， $\mu$ をイオン移動度 $\left(\mathrm{m}^{2} / \mathrm{V} / \mathrm{s}\right), E$ を電界強度 $(\mathrm{V} / \mathrm{m})$ とするとjは次の (4)式で表わさ机る。

$$
\frac{\partial^{2} \phi}{\partial r^{2}}+\frac{1}{r} \frac{\partial \phi}{\partial r}+\frac{\partial^{2} \phi}{\partial z^{2}}=0
$$




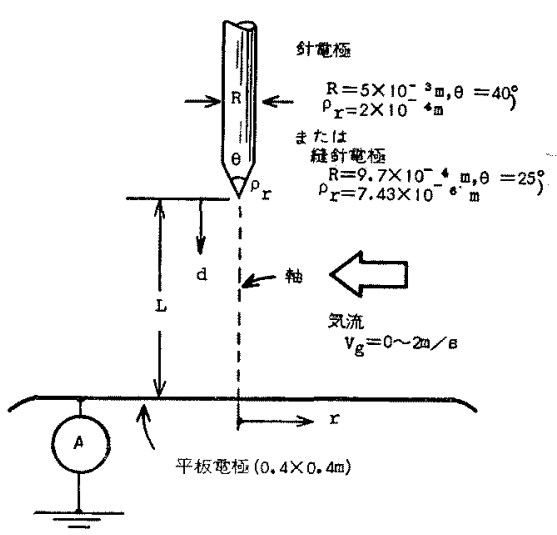

第 1 目奏験装置の概要

Fig. 1. Schematic diagram of needle to plate electrodes.

$j=\mu \rho E$

コンピュータで上記(1)〜（4)式妾解くにあたって 次の上うな手法を用いた。なお，てれらの式を解くに あたって，文献(13)を参考とした。

（1）㣂微分方程式を階差式にかえるにあたっては 四角形公式 ${ }^{(7)}$ (付録参照)を使用する。

（2）ポテンシャルの境界条件は，針表面を印加電 圧，平板表面を零電位とする。

（3）電流密度の境界条件は針先端のコロナ領域の 境界汃ら全コロナ電流が出ると仮定する〔計算を簡単 にするため, 格子間隔に相当する直径 $0.0025 \mathrm{~m}$ の球 面の下半面加ら，全電流加出る上仮定した。な招，文 献 (14)の第 4 図参照】。

（4）（1）式を繰返し法で収束さ甘るととは困難な ので，まず(3)式の解を求めて，との解老初期值とし て (1)，(2)式を交互に取束ささて求める。

上記手法を用いて雨電極間距雄 $L=0.05 \mathrm{~m}$, 印加電 圧 $V=-2.0 \times 10^{4} \mathrm{~V}, \exists$ 口十電流 $I=2.5 \times 10^{-5} \mathrm{~A}$, イオン移動度を $\mu=2.1 \times 10^{-4} \mathrm{~m}^{2} / \mathrm{V} / \mathrm{s}$ Łして(1)式の ポアソンの方程式の解を求めた。針刘平板電極では左 右対称なので右半面の電位パターンを第2 図に示す。 また，この条件の下に拈り平板上の電流密度分布 $j$ $\left(\mathrm{A} / \mathrm{m}^{2}\right)$ の計算值ならびに実験值第3図に示す。平 板上の電流密度测定に際してはプリント基板を用い， 板上に絶縁した $0.005 \times 0.005 \mathrm{~m}^{2}$ の微小正方形測定電 極を作成して，その電流値（2回の平均值）に基づい

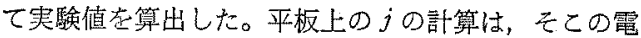
界強度として板上より一つ上方の格子点の値をとって 行なったのて，古る程度の誤差は免れない。しかし， $j$ の実験值と計算值之の閣にか子り良い一致が得られ

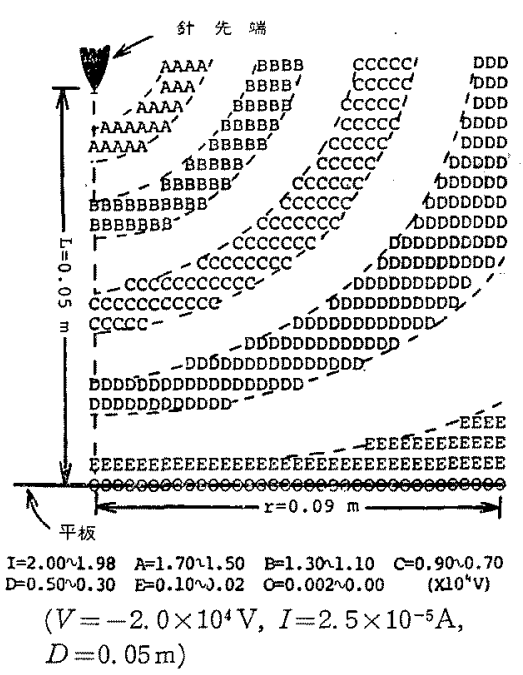

第 2 図 ポアンン方程式の計算結果による 電界分布パターン(第 1 図参照)

Fig. 2. Potential distribution pattern for the computated results of Poisson's equation (see Fig. 1).

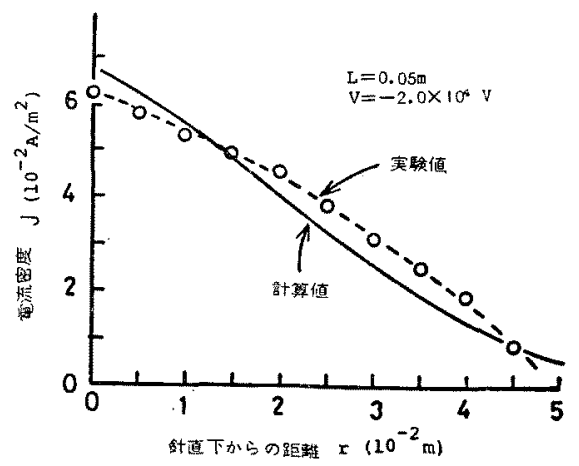

第 3 図 平板上電流密度分布

Fig. 3. Current density distribution on the plate electrode.

たことは，(1)式を解くにあたって用いた手法〔特に (2)〜 (4)項了が妥当であるととを示しているすのと 考えられる。

第 4 図は稞々の四加電压 $V$ に対して，計算によっ て求めた針先と, 平板を結んだ中心朝上の電界強度 $E$ の分布を平均電界強度 $E_{a v}=$ (印加電王) /(两䉓極間距 離) で規格化して表わしたものである。ここで，横軸 の $d=0$ が針先端で， $d=0.05 \mathrm{~m}$ が平板面に相当す る。 $d \geq 0.015 \mathrm{~m}$ の領域で対象とした印加電王の範国 では軸上電界にはほとんど差異が見られない。しかし 針先端に近付くにつれて印加電圧が高くなるほど軸上 電界が高くなく傾问加見られる。 


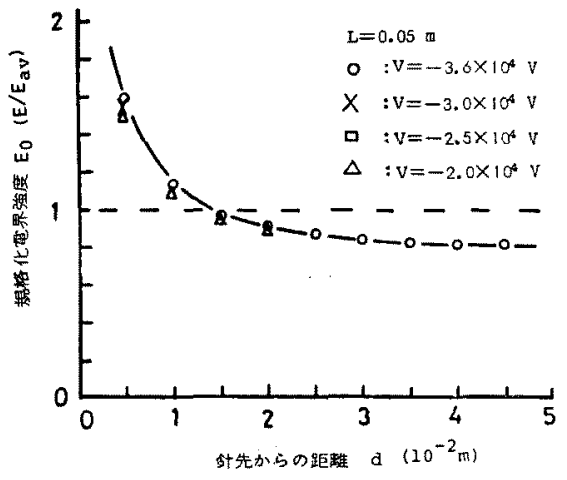

第 4 図 針対平板䉓極に拈ける軸上の 規格化電界強度特性

Fig. 4. Normalized electric field strength along the axis for the needle electrode against the plate electrode.

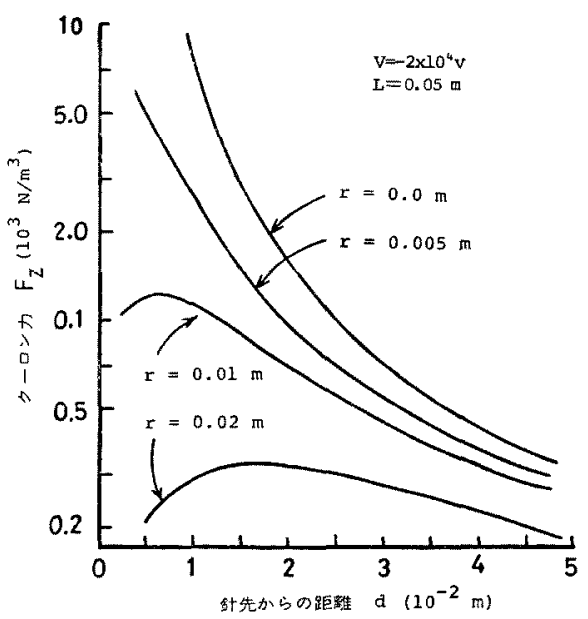

第 5 図 空間における平板への垂直成分の クーロン力密度分布(第 1 㳗参照)

Fig. 5. Coulomb force density distribution in the space for vertical component against the plate electrode (see Fig. 1).

第 5 図は印加電圧 $V=-2.0 \times 10^{4} \mathrm{~V}$ 亿括ける前記 クーロン力密度

$$
F_{z}=\rho_{z} E_{z}\left(\mathrm{~N} / \mathrm{m}^{3}\right)
$$

の計算値の平板方向の垂直成分の空間分布で，パラメ ータ $r$ は $r=0$ を中心韩上とした横方向の距離であ る。

\section{Navier-Stokes の方程式によるイオン 風速分布の計算}

〈3.1〉基礎方程式 イオン風の風速分布は次の Navier-Stokes の邁動方程式 (6) と連続の式 (7)加ら
求めることができる。

$$
\left.\begin{array}{l}
\frac{\partial u}{\partial t}+\frac{\partial u^{2}}{\partial r}+\frac{u^{2}}{r}+\frac{\partial u w}{\partial z} \\
=-\frac{1}{\rho_{g}}\left\{\frac{\partial p}{\partial r}-F_{\tau}\right\}+r\left\{\frac{\partial^{2} u}{\partial r^{2}}+\frac{\partial}{\partial r}\left(\frac{r}{u}\right)+\frac{\partial^{2} u}{\partial z^{2}}\right\} \\
\frac{\partial w}{\partial t}+\frac{\partial u w}{\partial r}+\frac{u w}{r}+\frac{\partial w^{2}}{\partial z} \\
=-\frac{1}{\rho_{g}}\left\{\frac{\partial p}{\partial z}-F_{z}\right\}+r\left\{\frac{\partial^{2} w}{\partial r^{2}}+\frac{1}{r} \frac{\partial w}{\partial r}+\frac{\partial^{2} w}{\partial z^{2}}\right\}
\end{array}\right\}
$$

但し， $u$, w は円筒座標 $(r, z)$ に打ける速塺成分 $(\mathrm{m} /$ s), $\rho_{\theta}$ 蚊気体密度 $\left(\mathrm{kg} / \mathrm{m}^{3}\right), p$ は気体王力 $\left(\mathrm{N} / \mathrm{m}^{2}\right)$, $F_{r}, F_{z}$ は円筒座標 $(r, z)$ に扎多外で，この場合 クーロン力密度 $\left(\mathrm{N} / \mathrm{m}^{3}\right), \gamma$ は気体の動祜性係数 $\left(\mathrm{m}^{2} / \mathrm{s}\right)$ である。な拉（5)式で外力として一般に表わされる 重力の項は，この場合流体が気体なので省略すること ができる。Dは速度の divergence であることはいう まですない。元して，上記 3 個の方程式 (6), (7) に おける未知数は $u$, w杍よび $p$ である。

こ扎らの方程式を産密に解くことは非常に困難で， 流れが復稚なときには不可能な䭪合が多い。そこで解 が得られるためにまず空気は非王縮性流体として取 报うことにし，乘に次に列記する乎法を用いて計算を 行なった。

（1）（6）式符1 項の時間項を考慮して，過涭過程 の計算定進め，針先近傍の测定值（レーザ・ドプラ流 遘計）に収柬した状態で定常解を得る。

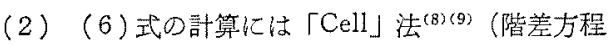
式）の手法を用いる。

（3）（6）式（7)式を解くには本諭文で提案する $\delta P$ 法 (後述) 在使用寸る。

(6)式を cell 法で表わす場合，生力 $p$ は常にその 階差 $\delta p$ 玨で表放，加ての㯖は十分に小さい。 そこで，てれに濐目し $\delta p$ 無視して（6)式を解き， 得られた結果に連続桑件 $(7)$ を組合せて解を修正する

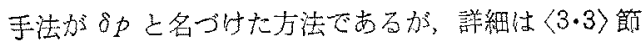
で述べる。ここで $\delta p$ 法の予備として，(6)式加ら压 力に対する次式究求めておく。

$$
\begin{aligned}
\nabla^{2} p= & \left\{\frac{\partial F_{r}}{\partial r}+\frac{\partial F_{z}}{\partial z}\right\}-\rho_{0}\left[\left\{\left(\frac{\partial u}{\partial r}\right)^{2}+\left(\frac{u}{r}\right)^{2}\right.\right. \\
& \left.+\left(\frac{\partial w}{\partial z}\right)^{2}+2 \frac{\partial w}{\partial r} \frac{\partial u}{\partial z}\right\}-\frac{\partial D}{\partial t} \\
& \left.-r\left(\frac{\partial^{2} D}{\partial r^{2}}+\frac{1}{r} \frac{\partial D}{\partial r}+\frac{\partial^{2} D}{\partial z^{2}}\right)\right] \ldots \ldots
\end{aligned}
$$




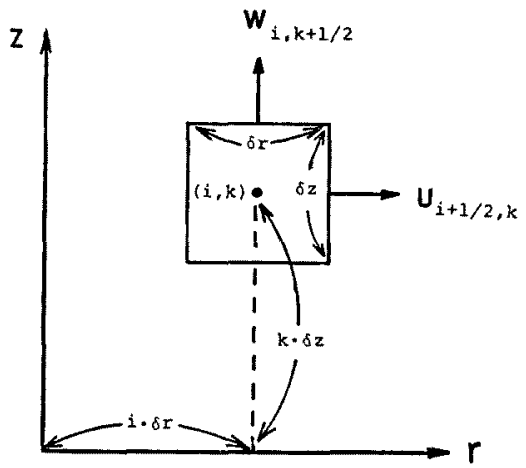

第 6 図 オイラーの cell $(i, k)$ に打竹る 速度成分

Fig. 6. Location of velocity components on a typical Eulerian cell $(i, k)$.

但し， (8)式の中の $D$ は零でないとして取扱う。

$\langle 3.2\rangle$ Cell 法 前章で空間の電界分布を求めた 各々の mesch point について，第6図に示すような 円筒座標書直した Cell $(i, k)$ を考元る。記号 $i, k$ はそれぞれ座標 $r, z$ の原点加ら数えた Ccell の番号 である。また，生力 $p_{i, k}$ と外力 $\left(F_{r}\right)_{i, k},\left(F_{z}\right)_{i, k}$ は Cell $(i, k)$ の中心作用するすのとする。このような Cell について，微分方程式を階差方程式传直した うえで計算するのが Cell 法(8)(9) である。ここで， (6)，(7) 式をCell 法で表わした式䘮次に示す。

$$
\begin{aligned}
& u_{i+1 / 2, k}^{n+1}=u_{i+1 / 2, k}+\delta t\left[\frac{\left(u_{i, k}\right)^{2}-\left(u_{i+1, k}\right)^{2}}{\delta r}\right.
\end{aligned}
$$

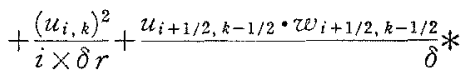

$$
\begin{aligned}
& * \frac{-u_{i+1 / 2, k+1 / 2} \cdot w_{i+1 / 2, k+1 / 2}}{z} \\
& -\frac{1}{\rho_{\theta}}\left\{\frac{p_{i, k}-p_{i+1, k}}{\partial r}-\left(F_{r}\right)_{i, k}\right\} \\
& +\gamma\left\{\frac{u_{i+3 / 2, k}-2 u_{i+1 / 2, k}+u_{i-1 / 2, k}}{(\delta r)^{2}}\right. \\
& -\frac{1}{i \times \delta r} \frac{u_{i, k}-u_{i+1, k}}{\delta r} \\
& \left.\left.+\frac{u_{i+1 / 2, k+1}-2 u_{i+1 / 2, k}+u_{i+1 / 2, k-1}}{(\delta z)^{2}}\right\}\right] \\
& w_{i, k+1 / 2}^{n+1}=w_{i, k+1 / 2}+\delta t\left[\frac{u_{i-1 / 2, k+1 / 2}}{\delta} *\right. \\
& * \frac{\cdot w_{i-1 / 2, k+1 / 2}}{r}-\frac{u_{i+1 / 2, k+1 / 2 \cdot w_{i+1 / 2, k+1 / 2}}}{\delta r} \\
& -\frac{\left(w_{i, k}\right)^{2}-\left(w_{i, k+1}\right)^{2}}{\delta z} \\
& -\frac{1}{\rho_{g}}\left\{\frac{p_{i, k}-p_{i+1, k}}{\delta z}-\left(F_{z}\right)_{i, k}\right\}
\end{aligned}
$$

$$
\begin{array}{r}
+\gamma\left\{\frac{w_{i+3 / 2, k}-2 w_{i+1 / 2, k}+w_{i-1 / 2, k}}{(\delta r)^{2}}\right. \\
-\frac{1}{i \times \delta r} \frac{w_{i, k}-w_{i+1, k}}{\delta r} \\
\left.\left.+\frac{w_{i+1 / 2, k}-2 w_{i+1, k}+w_{i+1 / 2, k-1}}{(\delta z)^{2}}\right\}\right] \\
\ldots \ldots \ldots \ldots \ldots \ldots \ldots \ldots . . \ldots \ldots \\
D_{i, k}{ }^{n+1}=\frac{u_{i, k}{ }^{n+1}-u_{i+1, k}{ }^{n+1}}{\delta r}+\frac{u_{i, k} n+1}{i \times \delta r} \\
\quad+\frac{w_{i, k}{ }^{n+1}-w_{i+1, k}{ }^{n+1}}{\delta z} \ldots \ldots
\end{array}
$$

ここで， $u^{n+1}, w^{n+1}$ は速度成分 $u^{n}, w^{n}$ の $\delta t$ 秒後の倠 であって，(9)式の右边のnは省略してある。なお， 定常状態では(10)式の右过は零であるが，過渡状態に おける解析を行なうので, これを零としないで取扱 う。また，u，wについて，次式に示す平均値の関係 が成立するものとする。

$$
\begin{aligned}
& u_{i+1 / 2, k+1 / 2}=\frac{1}{2}\left(u_{i+1 / 2, k}+u_{i+1 / 2, k+1}\right) \\
& w_{i+1 / 2, k+1 / 2}=\frac{1}{2}\left(w_{i, k+1 / 2}+w_{i+1, k+1 / 2}\right) \\
& u_{i, k}=\frac{1}{2}\left(u_{i-1 / 2, k}+u_{i+1 / 2, k}\right) \\
& w_{i, k}=\frac{1}{2}\left(w_{i, k-1 / 2}+w_{i, k+1 / 2}\right)
\end{aligned}
$$

ここで，針先端と平板を結ぶ中心軸上の軸公式は， (6)，(7)式について $r \rightarrow 0$ とした式を用いた。

〈3.3〉op 法 (6)式を解いて得られた速度 $u$, wは一般には(7)式の質量保存則を満足していない。 従って, 計算機で(6)式について $\delta t$ 悡ごとの繰返し 計算過程で (7)式の拘束条件を入れ，乙れによって解 に澌量保存，すなわち㣫続の関係を保持させなくては ならない。そこで，各々のCell については(10)式で 示される! Di, が零とならなくてはならない。皃しし雾 ではないとす㣗ば $D_{i, k}$ によってCell の表面に微小 圧为変化 $\delta p$ 紧生する。この $\delta p$ は近似的に次式で 示される。

$$
\left.\begin{array}{l}
\left(\delta p_{i, k}\right)_{r}=-\rho_{\theta} \frac{(\delta r)^{2}}{\delta t} D_{i, k} \\
\left\langle\delta p_{i, k}\right)_{z}=-\rho_{\theta} \frac{(\delta z)^{2}}{\delta t} D_{i, k}
\end{array}\right\}
$$

(12)式は本研究のスケール霸囲を考慮して，(8)式か ら近仅的に導出した。

まず（9)式の王力項は小さいのでこれを省略して 潓度 $u, w$ の諳算を行なう。次に得られた速度 $u, w$ 
の分布から(10)式により $D_{i, k}$ を計算し， これから (12)式により $\delta p$ を求める。次いで Cell 表面の速度

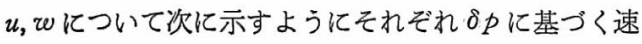
度微小変化を補正すれば結果的に連続の条件 (10)が注 たされたととになる。

$$
\left.\begin{array}{l}
u_{i+1 / 2, k} \longrightarrow u_{i+1 / 2, k}+\frac{1}{\rho_{g}} \cdot \frac{\delta t}{\delta r} \cdot\left(\delta p_{i, k}\right)_{r} \\
u_{i-1 / 2, k} \longrightarrow u_{i-1 / 2, k}-\frac{1}{\rho_{g}} \cdot \frac{\delta t}{\delta r} \cdot\left(\delta p_{i, k}\right)_{r} \\
w_{i, k+1 / 2} \longrightarrow w_{i, k+1 / 2}+\frac{1}{\rho_{g}} \cdot \frac{\delta t}{\delta z} \cdot\left(\delta p_{i, k}\right)_{z} \\
w_{i, k-1 / 2} \longrightarrow w_{i, k-1 / 2}-\frac{1}{\rho_{g}} \cdot \frac{\delta t}{\delta z} \cdot\left(\delta p_{i, k}\right)_{z}
\end{array}\right\}
$$

従って, $\delta t$ 秒後の空間の速度分布は $(9) \sim(13)$ の五つ の式を順序に従って解くことによって得られる。との $\delta t$ 秒ごとの過渡変化を経て，その収束値としての針対 平板における空間のイオン風速分布の定常值が計算さ れる。

なお，てれらの式を解くにあたって使用した境界条 件などは次のとおりである。

（1）外力の分布は前節のクーロン力密度分布とし た。

（2）速度の境界值は境界記号 $(i, k)$ の一つ少ない 值と同じとした。但し，針先端には実験值（レーザ・ ドプラ流速計) を用い, 平板面上の ひは零とした。 てのよう亿実験値を境界值として使用する点で，本計 算手法はまだ完全な解析的手法の域に達していない。

\section{4. 空間におけるイオン風速分布の測定}

〈4·1〉 シュリーレン法によるイオン風速分布の測 定この方法は次に述べるレーザ・ドプラ流速計に よる測定法に比較して，間接的で誤差が多いが，ほほ 針直下の軸上のイオン風速分布の大略の值を視覚的に はあくできる長所がある。

第 7 図に水平気流がない場合 ( a ) とある場合 ( b ) の イオン風コアのシュリーレン写真〔記入外の条件は文 献(2)と同じ〕を示す。水平気流がある場合には風下 の方へイオン風コアが流される。そとで, イオン風コ アの軌跡は水平気流と下方に向うイオン風コアでの風 速のベクトル合成と仮定し，既知の気流速度に基づい て多くの写真加らオン風速を求めた。これは，むち ろん軸上のイオン風速を与えるものでないことはいう までもないが, 一応その目安を与えるものと考えるこ とができる。ここで，軸上のイオン風速実験値として 針近傍の值は気流が大きい場合, 平板近くでは気流が

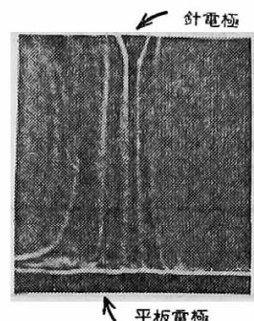

(a) $\mathrm{v}_{\mathrm{g}}=0.0 \mathrm{~m} / \mathrm{s}$

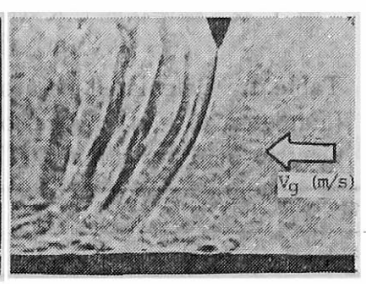

(b) $\mathrm{v}_{\mathrm{g}}=1.0 \mathrm{~m} / \mathrm{s}$
( $\mathrm{L}=0.05 \mathrm{~m}, \mathrm{~V}=2.5 \times 10^{4} \mathrm{v}$ )

第 7 図 気流によって負イオン風中心軌跡変 化を示すシュリーレン写真(第 1 図参照)

Fig. 7. Comparative Schlieren photographs of the central locus of negative ionic wind for various gas velocity.

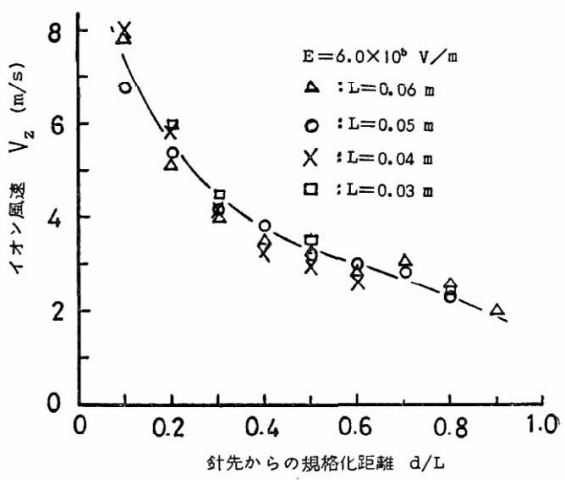

第 8 図 シュリーレン法による軸上の イオン風速分布

Fig. 8. Ionic wind velocity distribution along the axis by Schlieren method.

小さい場合の值を用いた。そして，実験値は同一条件 で測定した三つの值の平均をとってある。

平板電界強度 $E=6.0 \times 10^{5} \mathrm{~V} / \mathrm{m}$ 一定として, 両電 極間距離 $L$ を $0.03 \sim 0.06 \mathrm{~m}$ と変化させてむ, 横軸 を $L$ で規格化すると上記方法で求めたイオン風速 $v_{i}$ の測定分布は第 8 図に示すようにほぼ同一の曲線にな る。この図から, 平均電界強度が定まれば，Lが変化 してむイオン風速分布のパターンはほぼ一定となるこ とが予想される。

〈4·2〉 レーザ・ドプラ流速計による空間のイオン風 速分布 この方法は気体と同速度で移動している粒 子によるレーザ光のドプラシフトを測定することによ って，気体の速度を测定するものである。そこで第 1 図の針（この場合は縫針，図中の $\rho_{r}$ は針先端曲率半 径) 近傍から Smoke Generator(ロイコ社製)によっ て粒径 $0.3 \mu \mathrm{m}$ 前後の微粒子（フタル酸ジオクチル， 比誘電率 5.1) をイオン風速分布に影響を与えないよ

昭 $52-5$ 
符 1 表 標準状態で大気電界中の DOP 粒 子 $(0.3 \mu \mathrm{m})$ 移動速度の部算値

Table 1. Calculated values of DOP particle (diameter, $0.3 \mu \mathrm{m}$ ) migration velocity in an electric field for air at NTP.

\begin{tabular}{c|c|c|c|c|c}
\hline 電界强度 $\left(10^{5} \mathrm{~V} / \mathrm{m}\right)$ & 4.0 & 5.0 & 6.0 & 7.0 & 8.0 \\
\hline 炆子速应 $\left(10^{-2} \mathrm{~m} / \mathrm{s}\right)$ & 2.2 & 3.5 & 5.0 & 6.8 & 8.8 \\
\hline
\end{tabular}

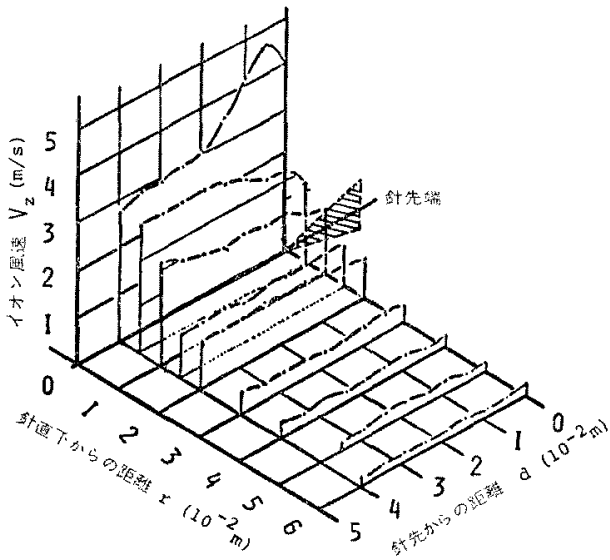

第 9 図 レーザドプラ流速計による空間の イオン痋速分析 $\left(V=-2.0 \times 10^{4} \mathrm{~V}\right.$, $D=0.05 \mathrm{~m}$ )

Fig. 9. Ionic wind distribution in the space by laser Doppler flowmeter.

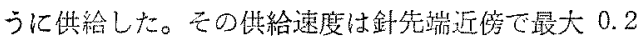
$\mathrm{m} / \mathrm{s}$ に止まった。粒子はイオンジャー店浴びて菏雷

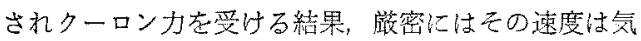
流速度加らず机るが力ニンガム補正係数 (11) 考虑し た。この粒子の電界中の速度(計算值)は第1表のと末 りで，十分に小さく、イオン風の测定值に姑大きな影 響はない。レーザ ドプラ流㻋計の测定精度をモータ にアクリル円板䘮取付けて回捏させ，その周边速度定

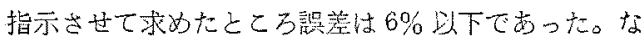
お，测定器自体の愦差しして，粒子整化基づくドプラ ・ビート周波数言只差加数％という報告(12)加古る。徒 ってこの方法によるイオン屈速の䋓合湘定誤差は,

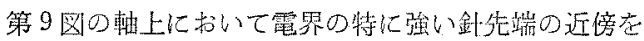
除いて国 10\% 程度と判断される*。

第 9 图は雨電極間距崔 $L=0.05 \mathrm{~m}$, 四加電压 $V=$

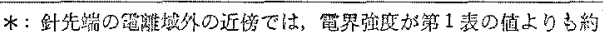

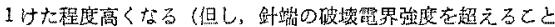

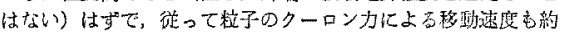

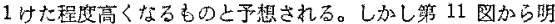

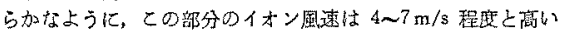
ので, この部分での躁差す $20 \%$ を超えるととはないすのと予 想される。
$-2.0 \times 10^{4} \mathrm{~V}$, コロナ電流 $I=2.5 \times 10^{-5} \mathrm{~A}$ の条件下に わけるレーザ・ドプラ流速計（日本科学工業製）で測 定したイオン風速度の平板力问成分の分布を示す。電 極装置索比較的小さなチャンバ $(0.6 \times 0.6 \times 0.6 \mathrm{~m})$ 内 に入れてあるため，計算の前提とした目由空間で生じ たイオン風の風棘分布とは若干異っているはずであ る。また，上記泟定竞差のため偏位 X が大きくなる ほご值の信頼度は小さくなるあのと年想される。しか し中心軸上の風趣分布は，シュリーレン法によって求 めた同一条件下の測定值しほぼ一致している。

$\langle 4 \cdot 3\rangle$ 計算結果と実験值との比較針対平板電 極における空間のクーロン力密度分布を第 2 章に示 した方法訓算し，乙れ荈外分布とする Navier. Stokes の式定，第 3 章で示した方法で解くことに上っ て空間のイオン風速分布が得られる。印加電圧 $V=$ $-2.0 \times 10^{4} \mathrm{~V}$, コロナ電流 $I=2.5 \times 10^{-5} \mathrm{~A}$, 丙電極間 距噰 $L=0.05 \mathrm{~m}$ の条件下で計算した空間のイオン風 速の平板方向成分の分析を第 10 図に示す。更保，同 一条件下でのレーザ ドプラ流速計による湘定結果 (第9図)在比較のため第 10 図に併記してある。 $0.01 \mathrm{~m}$ の㘯合には計算值と㬰測值との間に若下のず れがあるが，その他の位置では雨者の間にはかなり良 い一致が見られる。

第 11 图比扣電在 $V=-2.0 \times 10^{4} \mathrm{~V}$ と $V=-3.0$

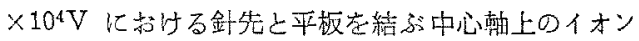

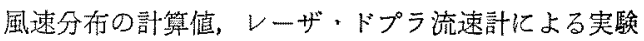
值，ショリーレン法による測定值の比較を示す。解析 計算の結果は，レーザ・ドプラ流速計による雪験值と はかなり良い一致を示している。シュリーレン法によ る実駼値だけがかなり低い值となっているが，この方

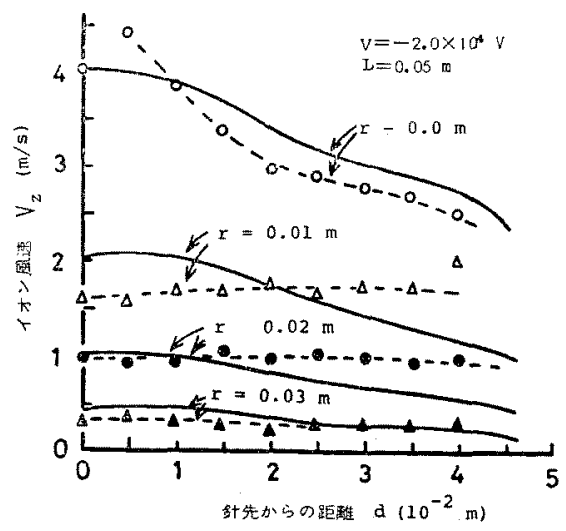

第 10 图空間化打るオオン風速特性

Fig. 10. Ionic wind velocity characteristics in the space by laser Doppler flowmeter and computational results. 


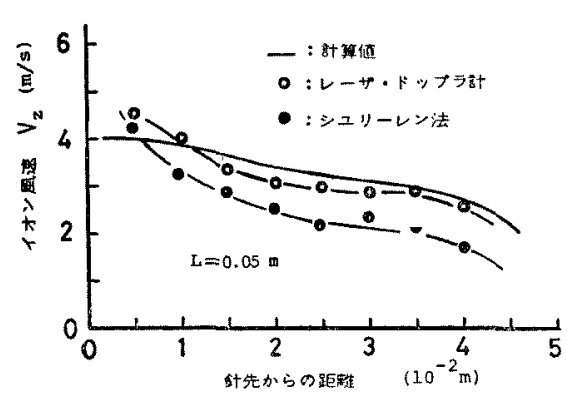

(s) $\mathrm{v}=-2.0 \times 10^{6} \mathrm{v}$

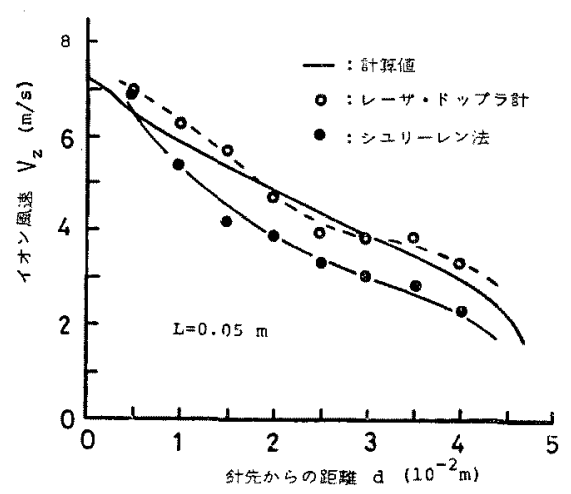

(b) $\mathrm{v}=-3.0 \times 10^{6} \mathrm{v}$

第 11 図 軸上に拈けるイオン風特性

Fig. 11. Ionic wind velocity characteristics along the axis.

法自体が原理的に愦善の大きいものである以上やむを 得ないものと思われる。

第 11 図比拉いて，針先端近傍 $(d<0.005 \mathrm{~m})$ のV 一ザ・ドプラ流速計による実験值（図中省略）は， $d$ $=0.005 \mathrm{~m}$ での值よりま小さな值を示した。

ここで, Robinson 氏(10)の式在用いた計算俌につい て検討する。彼は一次元の場合について，(5)式在压

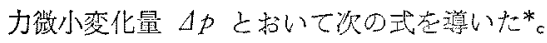

$$
v_{i}=\left[\frac{2}{k \rho_{g} \mu} \int_{0}^{L} j d L\right]^{1 / 2}
$$

但し， $k$ は損失係数，Lは雨電極間距雄である。いま 第 2 章で求めた空間の電位分布招よび電藏密度分布の

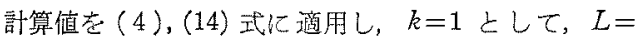
$0.05 \mathrm{~m}$ の針対平板電極の軸上について区分求積至行 なうと， $V=-2 \times 10^{4} \mathrm{~V}$ および $V=-3 \times 10^{4} \mathrm{~V}$ の場

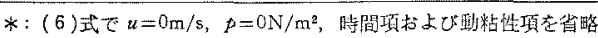

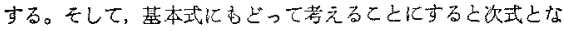
る。 $w \frac{\partial w}{\partial z}=\frac{F_{z}}{\rho_{g}}=\frac{\rho_{z} E_{z}}{\rho_{g}}=\frac{j_{z}}{\mu \rho_{g}}$ との式を䖽分すると， $k=1$ の䭪合の(14)式と一致する。
合について次の結果が得られた。

$$
\begin{aligned}
& v_{i}\left(-2 \times 10^{4} \mathrm{~V}\right)=7.1 \mathrm{~m} / \mathrm{s} \\
& v_{i}\left(-3 \times 10^{4} \mathrm{~V}\right)=11.8 \mathrm{~m} / \mathrm{s}
\end{aligned}
$$

こ扎らの值は，同一条件に対してレーザ・ドプラ流 速計で求めた粗上の最大实硢值約 $4 \mathrm{~m} / \mathrm{s}$ および $7 \mathrm{~m} / \mathrm{s}$ に比べる上著しく大きい。このことは钸対平板電極系 のように三次元の場に括けるイオン風速の計算には， (14)式のような簡略式は適用できないことを示してい 3。

\section{5. まとめ}

以上，針対平板電極に扣けるイオン風速の理端計算 ならびに実测結果をまとるると次のようになる。

(1) ポアソンの式と電流速続の式を解くことによ って，空間の電界扰よび霹荷密度分布ならびにクーロ ン力密度分布加得られた。乙の結果，算出された平板 上の電流密度分右は実殹傎との間にかなり良い一致を 示した。

（2）上記のクーロン力密度分布定外力密度分布上 して, Cell 法を用い, Navier-Stokes の式を解くこと によって空間のイオン風速の空間分布を算出した。こ の場合，新たに提案した「óp法」によって連続の条 件を満足させた。また䣄先端のイオン風速境界值とし てレーザ・ドプラ流速計による测定篗㺼用いた。

(3) 得られた空間のイオン風速然間分有の計算值 は、レーザ・ドプラ流速計による針先端以外の空閖に 扣ける测定值とかなり息い一致を示した。このととは 上記の計算法の妥当性少示寸もの之粗断さ㧈る。但し 璄界条件を零駼值に依拠しない計算法の開発は命後の 課題である。

（4）イオン風速の簡易推定法としてシュリーレン 法を提案した。このち法による值はレーザ・ドプラ流 速計による值に比ハて一船に低い值を示した。

以上で要䄪学終るが，EP 内でのイオン風がダスト

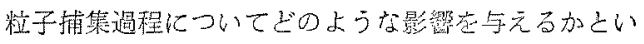
う間題については次の機会にゆずる。

最徭に，流体力学について鹤指奬いただいた東京大

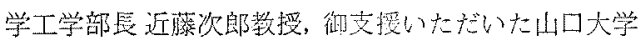

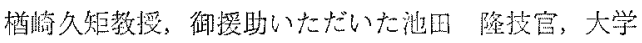
院学生下目 誠君（現不，日立製作所）に深く感謝す る次筙である。またレーザドプラ流㻋計について 援助いただいたサアザンプトン大学 J.D. Bassett 氏 に深鿒の謝意定表明する。

(昭和 51 年 6 月 17 日受竹, 同 51 年 11 月 15 日再受付) 


\section{文献}

(1) W. Deutsch: Ann. phys. 476, 729 (1925)

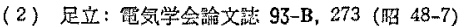

(3) M. Robinson: Am. phys. 30, 366 (1962)

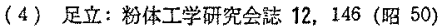

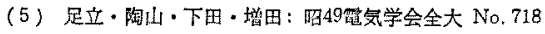

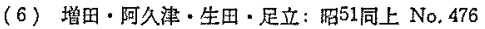

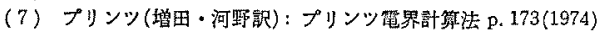

(8) C.W. Hirt \& J. L. Cook: J. Comp. phys. 10, 324(1972)

(9) F.H. Hareow \& J.E. Welch: phys. Fluids 12, $109(1965)$

(10) M. Robinson: Trans. AIEE 80, 143 (1961)

(11) H.J. White: Electrostatic Precipitation p. 157 (1963)

(12) H. Mishina, Y. Kawase \& T. Asakura: Japan J. App. Phy. 15, 633 (1976)

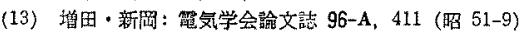

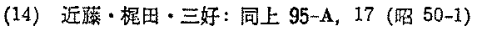

\section{付 録}

四角形公式 ${ }^{(7)}$ と一階偏微分の項 第 12 図に示す $z$ 軸加ら $s \partial r(=s h)$ の距離化ある0 点の電位 $\phi_{0}$ を 四角形公式で求めるためには，周围点電位 $\phi_{1}, \phi_{2}, \phi_{3}$, 名，が与えられていなくてはならない。これらの点の 電位についてテーラ展開定行なって, 三次の項以下を 省略すると次式办得られる。

$$
\begin{aligned}
& \phi_{1}=\phi_{0}+\delta z \frac{\partial \phi_{0}}{\partial z}+(\delta z)^{2} \frac{\partial^{2} \phi_{0}}{\partial z^{2}} \\
& \phi_{2}=\phi_{0}+\delta r \frac{\partial \phi_{0}}{\partial r}+(\delta r)^{2} \frac{\partial^{2} \phi_{0}}{\partial r^{2}} \\
& \phi_{3}=\phi_{0}-\delta z \frac{\partial \phi_{0}}{\partial z}+(\delta z)^{2} \frac{\partial^{2} \phi_{0}}{\partial z^{2}} \\
& \phi_{4}=\phi_{0}-\delta r \frac{\partial \phi_{0}}{\partial r}+(\partial r)^{2} \frac{\partial^{2} \phi_{0}}{\partial r^{2}}
\end{aligned}
$$

ここで, $\delta x=\delta y=h$ として（付 1) （付 4) 式の辺 々相加えて，(3)式のラプラスの式を代入すると次の 四角形公式加得られる。

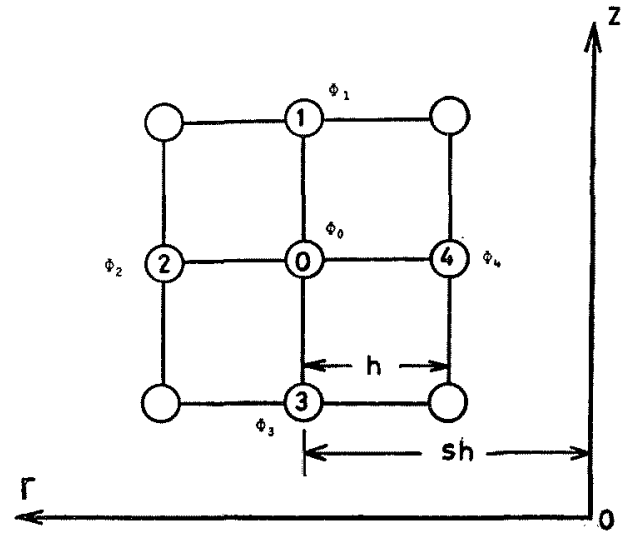

第 12 図 計算用格子に找ける格子点電位

Fig. 12. Variable value potential about a computational typical mesh.

$$
\phi_{0}=\frac{1}{4} \sum_{j=1}^{4} \phi_{j}+\frac{\phi_{2}-\phi_{4}}{8 s}
$$

また（1）式のポアソンの式を代入した場合には，次 の四角形公式上なる。

$$
\phi_{0}=\frac{1}{4} \sum_{j=1}^{4} \phi_{j}+\frac{\phi_{2}-\phi_{4}}{8 s}+\frac{h^{2} \rho_{0}}{2 \varepsilon} \ldots
$$

(付 1 )之(付 3 )式，および(付 2)之(付 4) 式の辺々 相差引いて，一階㵜微分の項を求令次のようにな る。

$$
\frac{\partial \phi_{0}}{\partial z}=\frac{\phi_{1}-\phi_{3}}{2 \delta z}, \frac{\partial \phi_{0}}{\partial r}=\frac{\phi_{2}-\phi_{4}}{2 \delta r}
$$

また（付 1)および(付 2)式で二次の項省略して， 一階偏微分項を求好ると次の上うになる。

$$
\frac{\partial \phi_{0}}{\partial z}=\frac{\phi_{1}-\phi_{0}}{2 \delta z}, \frac{\partial \phi_{0}}{\partial r}=\frac{\phi_{2}-\phi_{0}}{2 \delta r} \ldots
$$

(付 7 ) 式は二次近似であって，(付 8 )式は一次近似 である。との二つの式は (2), (6), (7) 式などの解法 にあたって，必要応じて使い分けた。 